\title{
USAHA PROFESIONALISME PENDIDIK YANG MENIMBULKAN POLEMIK
}

\author{
Oleh: \\ Fatimatus Zahro Jihan Fitri \\ Fakultas Saintek UIN Sunan Kalijaga Yogyakarta
}

\begin{abstract}
Abstrak
Pendidikan telah didefinisikan secara berbeda-beda oleh berbagai kalangan, yang banyak dipengaruhi pandangan dunia masing-masing. Kesimpulan awal bahwa pendidikan merupakan suatu proses penyiapan generasi muda untuk menjalankan kehidupan dan memenuhi tujuan hidupnya secara lebih efektif dan efisien. Pendidikan lebih dari sekedar pengajaran. Guru sebagai agen pembawa perubahan yang mampu mendorong pemahaman dan toleransi diharapkan tidak hanya mampu mencerdaskan peserta didik, tetapi juga harus mampu mengembangkan kepribadian yang utuh, berakhlak dan berkarakter. Dibutuhkan suatu proses pendidikan guru yang secara profesional dapat dipertanggungjawabkan. Guru profesional adalah guru yang dalam melaksanakan tugasnya mampu menunjukkan kemampuannya yang ditandai dengan penguasaan kompetensi akademik pendidikan dan kompetensi substansi sesuai dengan program studinya.
\end{abstract}

Kata kunci: profesionalisme, pendidik, polemik

\section{Pendahuluan}

Pendidikan telah didefinisikan secara berbeda-beda oleh berbagai kalangan, yang banyak dipengaruhi pandangan dunia masing-masing. Namun pada dasarnya, semua pandangan yang berbeda itu bertemu dalam semacam kesimpulan awal bahwa pendidikan merupakan suatu proses penyiapan generasi muda untuk menjalankan kehidupan dan memenuhi tujuan hidupnya secara lebih efektif dan efisien. Pendidikan lebih dari sekedar pengajaran. Perbedaan pendidikan dengan pengajaran terletak pada penekanan pendidikan dalam pembentukan kesadaran dan kepribadian anak didik disamping transfer ilmu dan keterampilan (Azra: 2001).

Guru sebagai agen pembawa perubahan yang mampu mendorong pemahaman dan toleransi diharapkan tidak hanya mampu mencerdaskan peserta didik tetapi juga harus mampu mengembangkan kepribadian yang utuh, berakhlak dan berkarakter. Untuk itu dibutuhkan suatu proses pendidikan guru yang secara profesional dapat dipertanggungjawabkan. Jadi untuk menyiapkan tenaga 
pendidik tidak hanya diperlukan suatu proses pendidikan akademik yang handal akan tetapi juga diperlukan suatu proses pendidikan yang mampu mengembangkan kepribadian dan karakter seorang pendidik.

Guru profesional adalah guru yang dalam melaksanakan tugasnya mampu menunjukkan kemampuannya yang ditandai dengan penguasaan kompetensi akademik pendidikan dan kompetensi substansi sesuai dengan program studinya. Profesional adalah pekerjaan atau kegiatan yang dilakukan oleh seseorang dan menjadi sumber penghasilan kehidupan yang memerlukan keahlian, kemahiran, atau kecakapan yang memenuhi standar mutu atau norma tertentu serta memerlukan pendidikan profesi.

Tak diragukan, guru merupakan pekerjaan dan sudah menjadi sumber penghasilan bagi begitu banyak orang, serta memerlukan keahlian berstandar mutu atau norma tertentu, sehingga untuk mengajar seorang guru harus memiliki kemampuan teoritik. Hanya guru yang berbekal pendidikan profesional keguruan yang bisa menegaskan dirinya memiliki pemahaman teoretik bidang keahlian kependidikan. Kualifikasi pendidikan ini hanya bisa diperoleh melalui pendidikan formal bidang dan jenjang tertentu.

Beberapa tahun terakhir ini, pemerintah telah menetapkan pendidikan profesi guru untuk mendapatkan sertifikat sebagai seorang pengajar. Program ini datang menggantikan program Akta IV yang sebelumnya menjadi program untuk mendapatkan sertifikat mengajar. Namun dalam pelaksanaannya, Pendidikan Profesi Guru mengundang berbagai macam masalah dan pertanyaan. Makalah ini akan membahas secara singkat tentang Pendidikan Profesi Guru dan bagaimana respon masyarakat atas keberadaan Pendidikan Profesi Guru.

\section{Pembahasan}

\section{Gambaran Guru Profesional}

Profesi merupakan pekerjaan, dapat pula berwujud sebagai jabatan di dalam suatu hierarki birokrasi yang menuntut keahlian tertentu serta memiliki etika khusus untuk jabatan tersebut serta pelayanan baku terhadap masyarakat. Inti dari pengertian profesi ialah seseorang harus memiliki keahlian tertentu. Pada masyarakat modern, keahlian tersebut diperoleh melalui pendidikan dan pelatihan 
khusus. Sebagai lawan dari profesi adalah amatir. Suatu profesi adalah kegiatan seseorang untuk menghidupi kehidupannya. Seorang amatir menekuni suatu kegiatan terutama karena hobi atau untuk mengisi waktu luang. Seorang profesional menjalankan pekerjaannya sesuai tuntutan profesi atau dengan kata lain memiliki kemampuan dan sikap sesuai dengan tuntutan profesinya (Tilaar: 2009).

Abad 21 merupakan abad global. Kehidupan masyarakat berubah dengan cepat karena dunia semakin menyatu apalagi ditopang dengan kemajuan teknologi informasi dan komunikasi sehingga batas-batas masyarakat dan negara menjadi kabur. Termasuk di dalam perubahan global ialah profesi guru. Sesuai dengan perubahan zaman, profesi guru juga menuntut profesionalisme. Guru yang profesional bukan hanya sekedar alat untuk transmisi kebudayaan tetapi mentransformasikan kebudayaan itu ke arah budaya yang dinamis yang menuntut penguasaan ilmu pengetahuan, produktifitas yang tinggi dan kualitas karya yang dapat bersaing. Guru profesional bukan lagi merupakan sosok yang berfungsi sebagai robot, tetapi merupakan dinamisator yang mengantar potensi-potensi peserta didik ke arah kreatifitas. Tugas seorang guru profesional meliputi tiga bidang utama yaitu bidang profesi, bidang kemanusiaan dan bidang kemasyarakatan.

Dalam bidang profesi, seorang guru profesional berfungsi untuk mengajar, mendidik, melatih dan melaksanakan penelitian masalah-masalah kependidikan. Dalam bidang kemanusiaan, guru berfungsi sebagai pengganti orang tua khususnya di dalam bidang peningkatan kemampuan intelektual peserta didik. Guru profesional menjadi fasilitator untuk membantu peserta didik mentransformasikan potensi yang dimiliki peserta didik menjadi kemampuan serta keterampilan yang berkembang dan bermanfaat bagi kemanusiaan. Dalam bidang kemasyarakatan, profesi guru berfungsi untuk memenuhi amanat dalam pembukaan UUD 1945 yaitu ikut serta dalam mencerdaskan kehidupan bangsa Indonesia.

Undang-undang Republik Indonesia Nomor 20 tentang Sistem Pendidikan Nasional pasal 39 ayat 2 menyatakan bahwa pendidik merupakan tenaga profesional yang bertugas merencanakan dan melaksanakan proses pembelajaran, menilai hasil pembelajaran, melakukan pembimbingan dan pelatihan, serta melakukan penelitian dan pengabdian kepada masyarakat, terutama bagi pendidik pada perguruan tinggi. Tilaar (1998) mengemukakan empat karakteristik guru profesional sebagai berikut, 
pertama, kepribadian yang matang dan berkembang. Profesi guru adalah profesi yang membantu dan membimbing perkembangan manusia, oleh sebab itu, guru harus memiliki karakter yang kokoh dan seimbang serta memiliki visi tentang etika tingkah laku manusia baik sebagai individu maupun sebagai anggota masyarakat.

Kedua, penguasaan ilmu pengetahuan dan teknologi yang kuat. Seorang guru profesional akan dapat membawa peserta didik untuk memasuki dunia ilmu pengetahuan dan teknologi yang terus berkembang. Agar dapat membimbing dan mengarahkan peserta didik, maka seorang guru harus memiliki bekal penguasaan ilmu pengetahuan dan teknologi.

Ketiga, keterampilan untuk membangkitkan minat peserta didik agar tertarik kepada ilmu pengetahuan dan teknologi. Seorang guru profesional harus menguasai kemampuan metodologis sebagai cara membangkitkan minat peserta didik akan ilmu pengetahuan dan teknologi. Kemampuan metodologis ini merupakan karakteristik yang membedakan guru dengan profesi lainnya.

Keempat, mengembangkan profesi secara berkesinambungan. Seorang guru profesional selayaknya tidak pernah berhenti berusaha mengembangkan kemampuan dirinya. Hal tersebut dapat dilakukan dengan mengikuti berbagai diklat dan seminar serta secara terus-menerus mengadakan penelitian di bidang pendidikan.

\section{Pengertian Pendidikan Profesi Guru}

Pemerintah menetapkan dasar hukum pendidikan profesi pada Undangundang Sisdiknas Nomor 20 Tahun 2003 Pasal 15 yang menyatakan bahwa jenis pendidikan mencakup pendidikan umum, kejuruan, akdemik, profesi, vokasi, keagamaan, dan khusus. Pendidikan profesi didefinisikan sebagai pendidikan tinggi setelah program sarjana yang mempersiapkan peserta didik untuk memiliki pekerjaan dengan persayaratan keahlian khusus.

Mengacu pada UU No. 20/2003 Pasal 3, tujuan umum program Pendidikan Profesi Guru adalah menghasilkan calon guru yang memiliki kemampuan mewujudkan tujuan pendidikan nasional, yaitu mengembangkan potensi peserta didik menjadi manusia yang beriman dan bertakwa kepada Tuhan 
Yang Maha Esa, berakhlak mulia, sehat, berilmu, cakap, kreatif, mandiri, dan menjadi warga negara yang demokratis serta bertanggung jawab.

Tujuan khusus program PPG seperti yang tercantum dalam Permendiknas No 8 Tahun 2009 Pasal 2 adalah untuk menghasilkan calon guru yang memiliki kompetensi dalam merencanakan, melaksanakan, dan menilai pembelajaran; menindaklanjuti hasil penilaian, melakukan pembimbingan, dan pelatihan peserta didik serta melakukan penelitian, dan mampu mengembangkan profesionalitas secara berkelanjutan.

Lembaga penyelenggara program Pendidikan Profesi Guru adalah perguruan tinggi yang memiliki program pengadaan tenaga kependidikan yang memenuhi persyaratan dan ditetapkan oleh menteri. Kriteria penunjukan LPTK sebagai penyelenggara program PPG ditentukan berdasarkan pemenuhan persyaratan yang terkait dengan akreditasi Badan Akreditasi Nasional Perguruan Tinggi (BAN-PT), ketaatan azas dalam penyelenggaraan perguruan tinggi sesuai dengan peraturan perundangan yang ada, komitmen LPTK dalam memberikan laporan, verifikasi lapangan untuk memeriksa kesesuaian antara proposal usulan penyelenggaraan program PPG dengan kenyataan sebenarnya seperti kualifikasi sumber daya manusia, kualitas sarana dan prasarana dalam pelaksanaan tri dharma perguruan tinggi yang mendukung program studi kependidikan dan Program Pengalaman Lapangan (PPL).

\section{Implikasi Keberadaan Pendidikan Profesi}

Pendidikan Profesi Guru dapat diikuti lewat dua jalur, yaitu jalur rekomendasi dan jalur seleksi. Jalur rekomendasi didapatkan lewat usulan dari pihak sekolah, yang kemudian diajukan untuk memenuhi kuota yang diberikan pemerintah. Sedangkan pada jalur seleksi, calon peserta mengajukan dan mempersiapkan semua persyaratan yang harus dipenuhi untuk kemudian diseleksi. Untuk menjadi peserta Pendidikan Profesi Guru, ada beberapa persyaratan yang harus dipenuhi sebagai berikut:

a. Memiliki kualifikasi akademik minimal sarjana (S-1) atau diploma empat (D-IV) dari program studi yang terakreditasi, kecuali guru SD dan guru PAUD. 
b. Mengajar di satuan pendidikan di bawah binaan Kementerian Pendidikan Nasional.

c. Guru PNS yang mengajar pada satuan pendidikan yang diselenggarakan oleh Pemda atau guru yang diperbantukan pada satuan pendidikan yang diselenggarakan oleh masyarakat.

d. Guru bukan PNS, yaitu guru tetap yayasan (GTY) atau guru yang mengajar pada satuan pendidikan yang diselenggarakan oleh Pemda.

e. Memiliki NUPTK.

f. Memiliki masa kerja sebagai guru minimal 5 tahun dengan usia maksimal 35 tahun pada saat mendaftar.

g. Memiliki prestasi akademik/non akademik dan karya pengembangan profesi di tingkat kab/kota, provinsi, atau nasional yang diselenggarakan oleh pemerintah pusat, pemerintah daerah maupun organisasi/lembaga.

h. Bersedia mengikuti pendidikan sesuai dengan peraturan terkait yang relevan dan mendapatkan izin belajar.

i. Surat keterangan berbadan sehat dari dokter.

j. Surat keterangan bebas napza (narkotika, psikotropika, dan zat aditif lainnya).

Peserta Pendidikan Profesi Guru adalah semua guru dan calon guru dalam posisi PNS atau CPNS atau guru tetap yayasan yang dianggap memenuhi syarat. Pelaksanaan program ini agak berbeda karena dalam satu kelas hanya diisi oleh guru yang memiliki satu rumpun ilmu pengetahuan. Artinya, setiap guru dikelompokkan berdasarkan bidang pelajaran yang menjadi kompetensi mereka. Penulis masih belum menemukan rincian anggaran yang diperlukan bagi tiap peserta yang dipilih pemerintah. Selain itu, pada panduan Pendidikan Profesi Guru, belum dijelaskan kurikulum secara detail, sehingga penulis tidak dapat menyimpulkan apa yang menjadi kelebihan program ini dibandingkan dengan kurikulum jurusan pendidikan. Pemerintah hanya menjelaskan, bahwa pada tahun 2011, kurikulum Pendidikan Profesi Guru ditujukan untuk menyeimbangkan kemampuan keilmuan dan pedagogik, ditambah dengan pendidikan karakter sebagai tindak lanjut dari evaluasi pelaksanaan Pendidikan Profesi Guru pada tahun 2010.

Dalam pandangan penulis, ada baiknya pemerintah mempertimbangkan bahwa sebaiknya pendidikan profesi guru hanya diperuntukkan bagi lulusan non 
kependidikan, mengingat lulusan jurusan kependidikan telah mendapatkan materi dan mempelajari berbagai seluk beluk ilmu dan metode pendidikan selama empat tahun. Lebih baik meningkatkan kualitas kurikulum pendidikan strata 1, daripada mengharuskan mereka mengikuti Pendidikan Profesi Guru. Selain lebih menghemat anggaran, cara tersebut juga lebih efektif dan efisien.

Menurut Muhammad Nuh (Menteri Pendidikan Nasional), ada lima prioritas penggunaan anggaran Kemdiknas pada tahun 2011, yaitu meningkatkan akses dan mutu pendidikan anak usia dini (PAUD) sebesar Rp 1,3 triliun, menuntaskan pendidikan dasar sembilan tahun $\mathrm{Rp} 7,2$ triliun,meningkatkan mutu pendidikan vokasi Rp 2,4 triliun, percepatan peningkatan kualifikasi akademik guru, sertifikasi dan rintisan pendidikan profesi guru $\mathrm{Rp} 8$ triliun, dan percepatan peningkatan jumlah dosen bergelar S3 sebesar Rp 2 triliun.

Peserta yang telah lulus Pendidikan Profesi Guru akan menyandang predikat guru bersertifikat dan pemerintah akan membayarkan tunjangannya seperti program sertifikasi. Itulah sebabnya maka Pendidikan Profesi Guru hanya diikuti oleh guru yang direkomendasikan oleh pemerintah. Pendidikan profesi guru bertujuan untuk menghasilkan guru-guru profesional dan berkualitas yang bisa meningkatkan mutu pendidikan di sekolah-sekolah. Pendidikan profesi guru taman kanak-kanak (TK) dan sekolah dasar (SD) dilaksanakan selama enam bulan, sedangkan pendidikan profesi guru untuk mata pelajaran di tingkat SMP, SMA dan SMK berlangsung selama satu tahun.

Banyak pihak yang membandingkan program Pendidikan Profesi Guru dengan program Akta IV. Namun, pada dasarnya terdapat perbedaan yang signifikan di antara kedua program tersebut. Pertama, Program Akta IV diambil untuk mendapatkan sertifikat ijin mengajar, sedangkan Pendidikan Profesi Guru diarahkan untuk mendapat sertifikat pengajar profesional yang digunakan untuk mendapatkan tunjangan sertifikasi. Kedua, program Akta IV diikuti oleh mahasiswa non kependidikan sedangkan program Pendidikan Profesi Guru diikuti oleh semua jurusan. Ketiga, program Akta IV dapat diikuti oleh siapa saja, sedangkan Pendidikan Profesi Guru hanya dapat diikuti oleh PNS atau CPNS. Keempat, untuk memasuki program Akta IV tidak perlu menjalani proses seleksi, sedangkan pada 
program Pendidikan Profesi Guru, terdapat beberapa tahapan seleksi dan selanjutnya peserta yang memenuhi syarat akan menjalani matrikulasi.

Berbagai tahapan yang dilakukan berkaitan dengan pelaksanaan Pendidikan Profesi Guru mengundang pertanyaan dalam benak penulis. Jika memang Pendidikan Profesi Guru dimaksudkan untuk mendapatkan sertifikat pendidik dan tunjangan sertifikasi, bukankah hal tersebut akan memerlukan lebih banyak dana daripada jika sertifikasi dilakukan lewat jalur portofolio. Untuk menjalankan program ini pemerintah harus menyediakan dana pendidikan bagi kuota yang telah ditentukan selama masa pendidikan, sedangkan pada jalur portofolio, pemerintah hanya menyediakan dana bagi panitia seleksi sertifikasi saja.

Berkenaan dengan penjaminan mutu dan kompetensi lulusan program Pendidikan Profesi Guru, masih banyak pihak yang mempertanyakan hal tersebut. Pelaksanaan program Pendidikan Profesi Guru mengharuskan guru dalam masa tugas untuk berbagi waktu mengajar dengan tugas belajar di kampus. Hal tersebut justru dapat berimbas negatif ke dalam dua aspek, yaitu menurunnya kualitas mengajar guru dan kurang maksimalnya pemahaman materi pendidikan profesi.

Program Pendidikan Profesi guru, pada dasarnya merupakan pembuka jalan bagi guru dalam masa jabatan yang tidak lulus sertifikasi lewat jalur portofolio. Jika melihat dari sudut pandang ini, Program Pendidikan Profesi Guru hanya terlihat sebagai "kereta kuda" untuk mendapatkan kompensasi sertifikasi. Jika demikian, efektifkah Program Pendidikan Profesi Guru dalam membentuk pendidik profesional ?.

Pemerintah mengisyaratkan bahwa secara perlahan-lahan sertifikasi portofolio akan dihapuskan mengingat banyak pihak menganggap hal tersebut tidak efektif. Banyak terjadi kasus dimana guru yang telah mendapatkan sertifikasi tidak menunjukkan kinerja yang meningkat bahkan justru sebaliknya. Pada dasarnya, guru yang mengajukan sertifikasi portofolio dan tidak lulus dapat menempuh jalur lain utuk mendapatkan sertifikasi, sehingga pada akhirnya setiap guru yang mengajukan sertifikasi akan mendapatkan tunjangan sertifikasi. Melihat sistem sertifikasi yang demikian mudah, penulis melihat bahwa fokus pemerintah bukanlah pada prestasi, namun balas budi terhadap profesi guru, sebab jika fokus pemerintah adalah 
prestasi, maka sistem seleksi, pelaksanaan dan evaluasi akan lebih ketat daripada sistem yang ada sekarang ini.

Ketika banyak pihak yang mempertanyakan perbedaan esensi antara Pendidikan Profesi Guru dengan Akta IV, pemerintah menjelaskan bahwa dari segi kualitas, lulusan program Pendidikan Profesi Guru layak menyandang predikat sebagai guru profesional karena untuk mendapatkan sertifikat mereka harus menjalani tes uji wawasan seperti tes potensi akademik, tes bahasa Indonesia, tes bahasa Inggris, psikotes, wawancara dan tes pedagogik, sementara pada pelaksanaan program Akta IV tidak terdapat tes semacam itu. Memang tak bisa dipungkiri bahwa rangkaian tes itu akan menjadi tes adrenalin bagi calon mahasiswa yang akan mengikuti Pendidikan Profesi Guru, tetapi menurut penulis tes tersebut tidak memiliki korelasi yang signifikan terhadap peningkatan mutu calon pendidik. Sistem pendidikan ini bahkan kelihatan cenderung dipaksakan dan seakan-akan memanggul kepentingan politik tertentu dari segelintir orang.

Pendidikan profesi kepada calon guru seyogyanya diperuntukkan bagi lulusan S1 atau D-IV non-kependidikan, karena materi ajar program S1 atau D-IV Kependidikan pada dasarnya telah memiliki dasar-dasar kompetensi yang diharapkan. Lain halnya bagi lulusan S1 atau D-IV non-kependidikan. Perlu pembekalan materi kompetensi pedagogik sebagai dasar keterampilan dalam mengelola pembelajaran. Calon guru TIK misalnya, sangat memerlukan penguasaan metodologi pengajaran untuk dapat melaksanakan tugas mengajar di sekolah.

Pendidikan Profesi Guru telah mulai dilaksanakan di beberapa perguruan tinggi yang telah ditunjuk pemerintah, namun pelaksanaan pendidikan profesi guru tersebut masih mengundang berbagai masalah yang menanti penyelesaian dan perhatian pemerintah. Salah satunya berkaitan dengan program Akta IV. Sebelumnya, program Akta IV merupakan SIM (surat Ijin Mengajar) bagi lulusan perguruan tinggi non kependidikan yang ingin menjadi guru. Program ini dilaksanakan selama satu semester dalam masa belajar atau sesudah lulus perguruan tinggi. Setelah ditetapkannya pendidikan profesi, banyak terjadi kebingungan dalam masyarakat. Pertama, ketidakseragaman keputusan antara perguruan tinggi di beberapa daerah. Beberapa perguruan tinggi di daerah masih membuka program ini dengan alasan belum ada ketentuan resmi dari pemerintah untuk mencabut program 
Akta IV dan juga dengan alasan terbatasnya akses dan fasilitas untuk melaksanakan pendidikan profesi. Selain itu, sertifikat Akta IV memiliki poin yang cukup tinggi untuk digunakan dalam portofolio proses sertifikasi guru, sehingga program Akta IV tetap diminati.

Masalah lain yang muncul setelah keberadaan Pendidikan Profesi Guru ialah sertifikat akta IV yang telah dimiliki oleh lulusannya dalam posisi mengambang, karena meskipun mereka telah dianggap lulus dan memiliki kompetensi sebagai pendidik, namun peraturan pemerintah mengharuskan mereka untuk menjalani pendidikan profesi jika ingin menjadi guru. Di sisi lain, saat ini pendidikan profesi masih belum membuka pendaftaran reguler, dan hanya menyelenggarakan pendidikan bagi guru dalam masa pra jabatan ataupun yang telah PNS, sehingga tidak setiap orang dapat mengikuti program ini.

Keadaan tersebut harus mendapatkan perhatian lebih dari pemerintah dan harus segera ditindaklanjuti. Ketidaktahuan masyarakat akan memiliki dampak negatif sehingga masyarakat pada akhirnya akan memiliki respon yang negatif pula terhadap berbagai kebijakan pemerintah. Pemerintah harus dapat membuktikan bahwa Pendidikan Profesi Guru memiliki kemasan dan isi yang berbeda dengan Akta IV, baik dari segi materi maupun keterampilan yang diberikan, mengingat peran guru yang memiliki multi fungsi. Setidaknya Pendidikan Profesi Guru dapat mengarahkan peserta untuk mengasah dan mengembangkan bukan hanya kemampuan intelektual mereka, namun juga kemampuan spiritual dan emosional yang sangat penting untuk diterapkan dalam kegiatan belajar mengajar. Pendidikan Profesi Guru selayaknya juga memiliki perubahan dalam kurikulum antara lain porsi praktek yang lebih besar sehingga penilaian kompetensi peserta lebih terlihat dan dievaluasi dengan lebih tepat.

Selama ini kita melihat bahwa pemerintah memiliki hobi mengubah sistem pendidikan dengan cepat, tanpa mempertimbangkan sistem eksplorasi dan sosialisasi secara maksimal terhadap sebuah program. Program Akta IV dan sertifikasi lewat jalur portofolio yang dalam pelaksanaannya belum tereksplor dengan baik, telah diganti dengan Program Pendidikan Profesi Guru. Hal ini masih diperparah dengan simpang siurnya informasi yang beredar di masyarakat tentang kebijakan pemerintah tersebut. Selain itu, tunjangan yang dijanjikan pemerintah bagi yang 
telah lulus Pendidikan Profesi Guru hingga saat ini belum berjalan dengan lancar. Di beberapa daerah, masih banyak guru yang belum mendapatkan tunjangan meskipun telah lulus selama berbulan-bulan. Ketidaksiapan sistem ini harus mendapat perhatian intensif dari pemerintah dan bukannya menebalkan muka dengan bersikap sesuka mereka. Jika hal ini terus berlanjut, sistem pendidikan untuk membentuk generasi yang berkualitas tidak akan terwujud karena pemerintah sebagai fasilitator belum memiliki kualitas yang pantas untuk mewujudkan hal tersebut. Meskipun menuai kontroversi, Pendidikan Profesi Guru memiliki kelebihan yaitu meningkatkan kualitas kemampuan mengajar guru, semua pendidik akan memiliki sertifikat profesional pada masa mendatang, materi dan metode pengajaran lebih intensif dan mengikuti perkembangan zaman, merupakan program lanjutan sertifikasi

Selain kelebihan, Pendidikan Profesi Guru juga memiliki kekurangan diantaranya: pelaksanaan pendidikan yang terkesan terburu-buru dilaksanakan, kebijakan pemerintah yang masih tumpang tindih, sosialisasi masih sangat minim di kalangan masyarakat, peserta terbatas hanya bagi CPNS, PNS atau guru tetap yayasan.

Ada beberapa faktor yang menjadi pendukung pelaksanaan Pendidikan Profesi Guru yaitu masih banyaknya guru yang belum memiliki kemampuan memadai dalam mengajar, sebagai jalan alternatif untuk mendapatkan sertifikasi. Selain itu, terdapat pula faktor yang menghambat pelaksanaan Pendidikan Profesi Guru sebagai berikut: Pelaksanaan Pendidikan Profesi Guru membutuhkan dana yang sangat besar, peserta dari daerah terpencil tidak memungkinkan mengikuti program ini, tidak semua perguruan tinggi membuka program ini

\section{Penutup}

Pendidikan Profesi Guru merupakan program pengganti Akta IV untuk mendapatkan sertifikat pendidik. Program ini merupakan program pemerintah yang memiliki tujuan mencetak guru-guru yang profesional. Saat ini, Pendidikan Profesi guru baru dilaksanakan di beberapa Perguruan tinggi yang ditunjuk pemerintah dan peserta perogram ini adalah para guru dalam masa jabatan yang ditunjuk atau direkomendasikan oleh pemerintah. 
Pendidikan Profesi Guru harus dapat menunjukkan perbedaan dalam kurikulum dan metodologinya jika tidak ingin disebut sebagai seragam baru pengganti Akta IV yang secara substansi tidak jauh berbeda. Jika Pendidikan Profesi Guru tidak dapat memperlihatkan "taringnya", akan lebih baik jika program ini dihapuskan agar tidak terjadi pemborosan anggaran negara.

\section{DAFTAR PUSTAKA}

Azra, azyumardi, Pendidikan Islam Tradisi dan Modernisasi Menuju Milenium baru, (Jakarta: Kalimah, 2001)

Bahtiar.net, Persayaratan Peserta PPG, http://bahtiar.net/2010/05/persyaratanpeserta-ppg/, diakses pada tanggal 10 Februari 2011

Compas.com, Nasib Calon Guru Terkatung-katung, http://edukasi.kompas.com diakses tanggal 5 Januari 2011

Direktorat Jenderal Pendidikan Islam Departemen Agama RI, Undang-undang Republik Indonesia Nomor 20 Tahun 2003, (Departemen Agama RI, 2006

Direktorat Jenderal Pendidikan Tinggi Kementerian Pendidikan Nasional, Panduan Pendidikan Profesi Guru, (Kementerian Pendidikan Nasional, 2010

http://www.waspada.co.id diakses pada tanggal 5 Januari 2011

Mata Guru, Anggaran Pendidikan Profesi Guru, http://mataguru.com/pendidikan/60-persen-pendidikan-ditransfer-kedaerah.html, diakses pada tanggal 10 Februari 2011

Tilaar, H.A.R, Beberapa agenda reformasi pendidikan nasional dalam perspektif abad 21, (Magelang: Tera Indonesia, 1998)

Tilaar, H.A.R, Membenahi Pendidikan Nasional, (Jakarta: Rineka Cipta, 2009)

Wordpress.com, Pendidikan Profesi Guru dimulai Tahun 2009, http://stembasurabaya.wordpress.com diakses tanggal 05 Januari 2011 